J. Product. \& Dev., 17(3): 345 - 353(2012)

\title{
BIOCHEMICAL STUDIES ON THE EFFECT OF Zn AND Cu ON THE CONTENT OF SOME CONSTITUENTS OF CORN GRAINS
}

\author{
A. Sharaf and R. A. Saber
}

Faculty of Technology and Development, Zagazig Univeristy, Zagazig, Egypt.

\begin{abstract}
The present work was carried out in field experiment at Ghazala Farm, Zagazig, Sharkia Governorate to study the effect of foliar application of $\mathrm{Zn}$ and $\mathrm{Cu}$ on the grain yield and some biochemical constituents of corn grains. The results obtained revealed that:-

The yield of corn grains was increased by the foliar application of any treatments from $\mathrm{Zn}$ or $\mathrm{Cu}$. Total and insoluble nitrogen content in corn grains were increased by all treatments and the highest values of soluble nitrogen were recorded by a mixture of $100 \mathrm{ppm} \mathrm{Zn}+\mathrm{Cu}$. Carbohydrate fractions slightly increased by any levels of $\mathrm{Zn}$ or $\mathrm{Cu}$ treatments, and the highest value recorded by the second level from $\mathrm{Zn}$ $+\mathrm{Cu}$. The oil content of corn grains was reduced by the adding all treatments especially in case Zn treatments. The application of 50 or $100 \mathrm{ppm} \mathrm{Cu}$ improved the total free amino acids content in corn grains while $\mathrm{Zn}$ treatments was decreased amino acids content. Phosphorus content in corn grains was increased by $\mathrm{Zn}$ treatments, while $\mathrm{Cu}$ treatments caused decreased phosphorus content. Also, Potassium content in corn grains was increased by the applications of $\mathrm{Zn}$ treatments and gave slightly decrease by $\mathrm{Cu}$ treatments.

In conclusion, the result of the present work suggested that the foliar application of any treatment from $\mathrm{Zn}$ on the corn grain, were increase increased yield, nitrogen fraction, and carbohydrate fraction, $P$ content but reduced oils content, and potassium content of corn grains, while, the application treatment from $\mathrm{Cu}$ increased the yield, nitrogen faction, carbohydrate content at low concentration and total free amino acid content, but improve oil content compared with foliar from $\mathrm{Zn}$ and reduce $P, K$ contents. Also, treatment application from mixed $\mathrm{Zn}$ and $\mathrm{Cu}$ on corn grain increased total $N$ content, yield but reduce $P, K$ and total free amino.
\end{abstract}

Key words: Biochemical Studies, Zn \& Cu, Corn Grains.

\section{INTRODUCTION}

Trace-elements are essential as plant growth, Although these elements are required in very small amounts, they are absolutely essential as 
they play a major role in plant metabolism because of its great importance in direct or indirect contribution with enzymes. $\mathrm{Zn}$ plays a role in the synthesis of hetero axine and its application increased the total and soluble nitrogen, as well as the protein content in plants (El-Sherbieny et al, 1981)

Fageria et al, (2002), Mahmood et al, (2006) and Ziaein \& Malkout (2001) found that $\mathrm{Cu}$ and $\mathrm{Zn}$ increased the biological value of protein, carbohydrate Fractions and starch content of grains. However, Barsoum (1980) reported the application of $\mathrm{Zn}, \mathrm{Fe}, \mathrm{Cu}$ and $\mathrm{Mn}$ as a foliar spray promoted carbohydrate metabolism in plant since it increased carbohydrate content of grains.

Also, Oury et al, (2005) and Hogye \& Fangrneier (2008), found that the Foliar spray of $\mathrm{Zn}, \mathrm{Cu}, \mathrm{Mn}$ improved the total amino acids contents in wheat grains such as $\mathrm{Zn}$ may be diluted by increasing yield.

Therefore, the aim of this work was to study the effect of spraying different levels of $\mathrm{Zn}$ and $\mathrm{Cu}$ on the yield components, nitrogen fractions, carbohydrate fractions, oil content, free amino acids and some nutrients of corn grains.

\section{MATERIALS AND METHODS}

A randomized complete block experiment with three replications was conducted at Ghazala Farm, Zagazig, Sharkia Governorate in the season (2010/2011) to study the effect of $\mathrm{Zn}$ and $\mathrm{Cu}$ on the yield and some biochemical contents of corn grains. Foliar application treatments were applied single or several combinations in two equal parts, the first part was applied at thining stage ( 25 day from swing) and the second part was applied at knee high stage (50 day from sowing). The treatments applied as following:
1- Control
2- $50 \mathrm{ppm} \mathrm{Zn}$
3- $100 \mathrm{ppm} \mathrm{Zn}$
4- $50 \mathrm{ppm} \mathrm{Cu}$
5- $100 \mathrm{ppm} \mathrm{Cu}$
6- $50 \mathrm{ppm} \mathrm{Zn}+\mathrm{Cu}$
7- $100 \mathrm{ppm} \mathrm{Zn}+\mathrm{Cu}$.

\section{Methods Of Analysis:}

- Total nitrogen was determined according to the method described by A.O.A.C. (1970).

- Soluble nitrogen was extracted with $50 \mathrm{ml}$ ethyl alcohol (75\%) and dried at $55^{\circ}$ under vacuum and dissolved in mixture of distilled water and chloroform (1:1). The soluble nitrogen was determined according to the method described by Mengle and Helal (1968).

- Insoluble nitrogen was determined by subtracting the amount of soluble from the total nitrogen.

- Carbohydrate fractions were determined according to the method of Magnetski et al (1959). 
- Free amino acids were extracted fractionated and determined as described by Block et al (1958).

- Phosphorus determined according to the method adapted by Agiza et al (1960).

- Potassium, was determined using atomic absorption apparatus in the acid digest according to the method of Chapman and Parker (1961).

- Oil percentage was determined by extracting in soxhelt apparatus by Petroleum ether according to the method described in A.O.A.C. (1970).

\section{RESULTS AND DISCUSSION}

It can be easily seen from Table 1 . The grain yield increased when corn plants were treated with all treatments application when compared with control. Such results might be due to the effect of micro elements on some physiological processes in plant. The highest grain yield recorded by treating $\mathrm{Zn}+\mathrm{Cu}$, but the lowest increase of grain yield was obtained by applied the first level of one. These results agree with those obtained by Sharaf et al (1984) who found. that foliar application of $\mathrm{Zn}, \mathrm{Fe}$ and $\mathrm{Mn}$ significantly increased the yield of grain and straw if compared with control. Also, Natasha and Mary (2006) found that $\mathrm{Zu}$, Fe and $\mathrm{Cu}$ improved the quality of corn grains. With regard the weight of 100 kernels the data revealed that, it was generally increased as a result of all treatments.

Table 1. Effect of $\mathrm{Zn}$ and $\mathrm{Cu}$ on the corn grain yield and weight of 100 kernels

\begin{tabular}{|c|c|c|c|c|}
\hline Treatments & Gm/Plant & $\begin{array}{c}\text { Kg/Plot } \\
\text { 1/300 Feddan }\end{array}$ & Kg/Feddan & $\begin{array}{c}\text { Weight of } \\
100 \text { kernel } \\
\text { (gm) }\end{array}$ \\
\hline 1- Control & 205 & 16.45 & 4935 & 25.72 \\
\hline 2- 50 ppm Zn & 212 & 18.25 & 4575 & 26.50 \\
\hline 3- 100 ppm Zn & 219 & 19.51 & 5853 & 28.60 \\
\hline 4- 50 ppm Cu & 222 & 19.78 & 5934 & 29.06 \\
\hline 5- $100 \mathrm{ppm} \mathrm{Cu}$ & 226 & 19.96 & 5988 & 28.92 \\
\hline 6- 50 ppm Zn+Cu & 231 & 20.31 & 6093 & 27.11 \\
\hline 7- 100 ppm $\mathrm{Zn}+\mathrm{Cu}$ & 229 & 20.08 & 6024 & 28.98 \\
\hline L.S.D $5 \%$ & - & 0.832 & - & - \\
\hline $1 \%$ & - & 1.166 & - & - \\
\hline
\end{tabular}

Results, recorded in Table (2) showed that the content of insoluble and total nitrogen were increased by spraying $\mathrm{Zn}$ or $\mathrm{Cu}$ treatments. The highest increase noticed with spraying corn plants $100 \mathrm{ppm} \mathrm{Zn}+\mathrm{Cu}$, when compared with the other treatments. This is probably from the fact $\mathrm{Zn}$ plays an important role in protein synthesis. These results agree with those reported by Sharaf et al (1984) and Hogye \& Fangrneier (2008). 
El-Sherbiny et al (1981) who reported that the content of total nitrogen in grains increased by the application of $\mathrm{Zn}$ or $\mathrm{Cu}$ either mixed or not. From the same table, it can be noticed also that the values of soluble nitrogen slightly increased by treatments where $\mathrm{Zn}$ application reduced the soluble nitrogen. This may be explained on the bases that $\mathrm{Zn}$ and $\mathrm{Cu}$ increase the nitrogen fixation as well as the synthesis of insoluble nitrogen. Such results agree with those obtained by Lixandra et al (1979) who found that the application of some trace-elements to plants increased the nitrogen content in soybean plants.

Table 2. Effect of $\mathrm{Zn}$ and $\mathrm{Cu}$ on the content of nitrogen fractions of corn grains(gm/100gm dry weight).

\begin{tabular}{|c|c|c|c|c|}
\hline Treatments & $\begin{array}{c}\text { Soluble } \\
\mathbf{N}\end{array}$ & $\begin{array}{c}\text { Insoluble } \\
\mathbf{N} \\
\end{array}$ & $\begin{array}{c}\text { Total } \\
\mathbf{N} \\
\end{array}$ & $\begin{array}{c}\text { Ratio } \\
\text { Gol./insol }\end{array}$ \\
\hline 1- Control & 0.144 & 1.265 & 1.409 & 0.114 \\
\hline 2- $50 \mathrm{ppm} \mathrm{Zn}$ & 0.135 & 1.502 & 1.637 & 0.090 \\
\hline 3- 100 ppm Zn & 0.129 & 1.623 & 1.752 & 0.079 \\
\hline 4- $50 \mathrm{ppm} \mathrm{Cu}$ & 0.159 & 1.409 & 1.568 & 0.113 \\
\hline 5- $100 \mathrm{ppm} \mathrm{Cu}$ & 0.156 & 1.382 & 1.538 & 0.113 \\
\hline 6- 50 ppm Zn $+\mathrm{Cu}$ & 0.162 & 1.448 & 1.610 & 0.112 \\
\hline 7- $\quad 100 \mathrm{ppm} \mathrm{Zn}+\mathrm{Cu}$ & 0.168 & 1.492 & 1.660 & 0.113 \\
\hline
\end{tabular}

Data in Table (3) show that the total free amino acids in corn grains was slightly decreased by foliar spray all treatments, but the foliar $\mathrm{Cu}$ treatments slightly increased the total free amino acids in corn grains, especially valine, aspartic, tyrosine and methionine. Also, it can be noticed that, the acidic amino acids showed comparatively the highest values when compared with other groups amino acids in corn grains. Also, from the same table, it can be easily seen that, inter the group aliphatic free amino acids, glycine was higher than alanine or valine.

Similar results were obtained in aromatic free amino acids and acidic free amino acids. This may be consumed in the biosynthesis of protein which may be stimulated by the treatment and accompanied with the decrease of soluble nitrogen. These results are in agreement with these obtained by Schedeve \& Dep (1977), Sharaf \& Youssef (1987) and Sitohy \& Sharaf (1986).

Date represented in Table (4) showed that foliar application of any micronutrient in most cases increased the insoluble and total carbohydrate fractions of corn grains and the greatest increase was recorded by the second level of $\mathrm{Zn}+\mathrm{Cu}$ when compared with control. This may be due to the increase in the concentration of photosynthetic pigments which was reflected on carbohydrates biosynthesis. The highest values of soluble carbohydrate fractions was obtained by $100 \mathrm{ppm} \mathrm{Zn}$ treatments. This means that $\mathrm{Zn}$ and $\mathrm{Cu}$ enhanced the carbohydrate metabolism in the plants. It is interesting to note that 
Table 4. Effect of $\mathrm{Zn}$ and $\mathrm{Cu}$ on the content of carbohydrate fractions in corn grains ( $\mathbf{G m} / \mathbf{1 0 0}$ gm dry weight).

\begin{tabular}{|c|c|c|c|c|}
\hline \multirow{2}{*}{ Treatment } & \multicolumn{3}{|c|}{ Carbohydrate fractions } & \multirow{2}{*}{ Ratio sol/insole } \\
\hline & Sol. & Insole. & Total & \\
\hline 1- Control & 11.77 & 66.76 & 78.53 & 0.176 \\
\hline 2- 50 ppm Zn & 11.06 & 67.96 & 79.02 & 0.163 \\
\hline 3- 100 ppm Zn & 12.09 & 68.55 & 80.64 & 0.176 \\
\hline 4- 50 ppm Cu & 10.30 & 68.94 & 79.24 & 0.149 \\
\hline 5- 100 ppm Cu & 11.24 & 68.95 & 80.27 & 0.163 \\
\hline 6- 50 ppm $\mathrm{Zn}+\mathrm{Cu}$ & 11.82 & 68.82 & 80.64 & 0.172 \\
\hline 7- $\quad 100$ ppm $\mathrm{Zn}+\mathrm{Cu}$ & 11.34 & 69.68 & 81.02 & 0.163 \\
\hline
\end{tabular}

Table 5. Effect of $\mathrm{Zn}$ and $\mathrm{Cu}$ on the content of oil and some properties in corn grains.

\begin{tabular}{|c|c|c|c|c|c|}
\hline \multirow{2}{*}{ Treatments } & \multicolumn{2}{|c|}{ Oil content } & \multicolumn{3}{|c|}{ Oil properties } \\
\hline & $\%$ & mg/plant & $\overline{\text { A.value }}$ & Sap.value & Iod.value \\
\hline 1- Control & 0.055 & 11.28 & 0.65 & 186.1 & 149.5 \\
\hline 2- 50 ppm Zn & 0.039 & 8.27 & 0.65 & 186.1 & 149.7 \\
\hline 3- $\quad 100$ ppm Zn & 0.035 & 8.02 & 0.65 & 187.5 & 149.7 \\
\hline 4- 50 ppm Cu & 0.044 & 9.51 & 0.71 & 187.5 & 149.4 \\
\hline 5- $100 \mathrm{ppm} \mathrm{Cu}$ & 0.047 & 11.01 & 0.73 & 188.1 & 149.5 \\
\hline 6- $\quad 50$ ppm $\mathrm{Zn}+\mathrm{Cu}$ & 0.035 & 8.73 & 0.59 & 188.4 & 149.8 \\
\hline 7- 100 ppm Zn+Cu & 0.045 & 10.31 & 0.55 & 187.5 & 149.6 \\
\hline
\end{tabular}

Ashour and Hegazi (1972) found that $\mathrm{Zn}$ as foliar spray on wheat plants increased the total carbohydrate content of grains.

Data in Table (5) indicated that spraying of $\mathrm{Zn}$ or $\mathrm{Cu}$ treatments decreased the concentration of oil content in corn grains. The highest decrease in oil content resulted from the added $100 \mathrm{ppm} \mathrm{Zn}$ and mixture the first level from $\mathrm{Zn}$ or $\mathrm{Cu}(50 \mathrm{ppm})$. In this respect, it is worthy to mention that El-Moursi and Saad (1980) noticed that oil content of soybean seed was decreased by some micronutrients applied.. On the other hand, the oil properties of corn grains, acid value, saponification value iodine value did not show any substantial changes as treating the plants with zn treatments, while cu treatments caused slightly increased the acid value. These results are in full agreement with those obtained by Sitohy and Sharaf (1986).

The results in Table (6) show that, the effect of $\mathrm{Zn}$ and $\mathrm{Cu}$ treatments upon the content of $\mathrm{P}$ and $\mathrm{K}$ in corn grains. $\mathrm{P}$ content in corn grains was increased by sprayed with the first level and second level of $\mathrm{Zn}$ treatments. Wheares, the lowest value of $\mathrm{P}$ was obtained from plants sprayed with $\mathrm{Cu}$ treatments. In this connection, Fuehring (1969), Barsoum 
Table 6. Effect of $\mathrm{Zn}$ and $\mathrm{Cu}$ on the content of phosphorus and potassium in corn grains

\begin{tabular}{|c|c|c|c|c|}
\hline \multirow{2}{*}{ Treatment } & \multicolumn{2}{|c|}{ Phosphorus } & \multicolumn{2}{|c|}{ Potassium } \\
\hline & $\%$ & mg/plant & $\%$ & mg/plan \\
\hline 1- Control & 1.584 & 324.92 & 3.689 & 756.24 \\
\hline 2- 50 ppm Zn & 1.896 & 402.10 & 4.112 & 899.94 \\
\hline 3- $\quad 100$ ppm Zn & 1.793 & 392.66 & 4.199 & 919.61 \\
\hline 4- 50 ppm Cu & 1.443 & 320.45 & 3.406 & 756.15 \\
\hline 5- $100 \mathrm{ppm} \mathrm{Cu}$ & 1.481 & 333.18 & 3.316 & 749.42 \\
\hline 6- 50 ppm Zn + Cu & 1.284 & 296.71 & 4.001 & 924.45 \\
\hline 7- 100 ppm Zn + Cu & 1.277 & 292.58 & 3.311 & 758.22 \\
\hline
\end{tabular}

(1980) and Ashour and Hegazi (1972), suggested that Zn treatment caused an increase in $\mathrm{P}$ content in grains.

From the same Table (6) that potassium content in corn grains was increased by $\mathrm{Zn}$ treatment when compared with control. Similar results were obtained by Fuehring (1969) show that potassium content in grains was at a maximum value in plants sprayed with $\mathrm{Zn}$ treatments.

In conclusion, the result of the present work suggested that the foliar applications of any treatment from $\mathrm{Zn}$ on the corn grain, were increase increased yield, nitrogen fraction, and carbohydrate fraction, P content, but reduced oils content and potassium content of corn grains, while, the application treatment from $\mathrm{Cu}$ increased the yield, nitrogen faction, carbohydrate content at low concentration and total free amino acid content, but improve oil content compared with foliar from $\mathrm{Zn}$ and reduce $\mathrm{P}, \mathrm{K}$ contents. Also, treatment application from mixed $\mathrm{Zn}$ and $\mathrm{Cu}$ on corn grain increased total $\mathrm{N}$ content, yield but reduce $\mathrm{P}, \mathrm{K}$ and total free amino.

\section{REFERENCES}

Agiza, A.H., El-Heneidy and Ibrahim, M (1960). the determination of the different fractions of phosporus. Faculty of Agriculture, Cairo Univeristy, Bill. N., 122-127.

Ashour, N.I. and Hegazi, S.M. (1972). Response of wheat to foliar nutrition with mieronutrients under Egyptian conditions. Egyptian $J$. Bot., 15: 95-102.

A.O.A.C. (1970). Official and Tentative Methods of Analysis. Associations of Official Agriculture Chemists. Washington D.C. $11^{\text {th }}$ Ed.

Barsoum, M.S. (1980). Response of wheat to micronutrients. M.SC. Thesis, Faculty of Agricultre Sci., Moshtohor, Zagazig Univ., Zagazig, Egypt.

Block, R.J. ; Durrum, E.L. and zweig, G. (1958). A Manual Of Paper Chromatography And Electrophoresis. Acad. Press Inc. New York. 
Chapman, H.D. and Parker, F.P (1961). Methods Of Analysis Of Soil, Plants And Water. Univ. of California, August 1981, $2^{\text {nd }}$ printing.

El-Moursi, And Saad, A.O. (1980). Research Bulletin. Faculty of Agriculture, Ain Shams University, Egypt.

El-Sherbiny, A.F.; Gaber, S. and Doheem, M. (1981). Effect of defieciency and applicaton of $\mathrm{Zn}$ and $\mathrm{Cu}$ on the biochemical constituents in wheat grains. Zagazig Univ., Res. Bull, No. 254.

Fageria, N.K. ; Buligr, V.C. and Clank, R.B. (2002). Micronutrient in Crop Production. Advances in Agronomy, New York, 79: 189-272.

Fuehring H.D. (1969). Irrigated wheat on a calcareous soil as affected by application of N.P.K. and Zn. Agron. Journal, 61: 501-504.

Hogy, P. and Fangmeier, A. (2008). Effect of elevated atmospheric $\mathrm{CO}_{2}$ on grains quality wheat. Journal Of Cereal Science, 48: 580-591.

Lixandra, G. ; Tarnouceonu, E. and Ciurea, G. (1979). Ionlones $\mathrm{Cu}$ Detabrad, Lasi, Agronomic, 33: 63-56.

Magnetski, K.P. ; Tsugarov, Y.A. and Malkov, 15.k. (1959). New Methods For Plant And Soil Analysis. Agriculture Acad. Press, UMB, Rell - Burris - Stauffer.

Mahmood, M., Wahdan, B.A. and Awath, A.B. (2006). Response wheat and maize cropping sequence in a calcarious soil to some mineral or chelated micronutrients forms added to soil in combination Fayoun. Journal of Agriculture Research, 25-39.

Mengle, K. and Helal, M. (1968). The effect of varied nitrogen and Potassium nutrition on the content of soluble amino compounds in serial parts of Oats. Z. Pflanzener, Naher. Bodenk, 12-20.

Natasha, G. and Mary, L.G. (2006). Molecular aspects of $\mathrm{Cu}, \mathrm{Fe}$ and $\mathrm{Zn}$ homeostasis in plant. Biochimica et Biophysica Acta, 595-608.

Oury, F.X. ; Leenhard, F. ; Remesy, c. and Duperrier, B. (2005). Genetic variability and stability of grains, $\mathrm{Mn}, \mathrm{Zn}$ and $\mathrm{Fe}$ concentration in wheat. European J. of Agronomy, 25: 177-185.

Sharaf, A.L. ; Awad, E. and Fouda, E. (1984). Effect of different sources of micronutrients on the yield quality of wheat. Annals of Agriculture Science, Moshtohor, Zagazig Univ., Zagazig, Egypt.اين ارقام الصفحات

Sharaf, A. and Youssef, A. (1987). Effect of some foliar compounds on yield and some biochemical constituents of barley plants. Annals of Agriculture Science," Moshtohor, Zagazig Univ., Zagazig, Egypt, 25 (2): اين ارقام الصفحات

Schedeve, F. and Dep, O.L. (1977). Effect of $\mathrm{Zn}$ on Protein and RNA Content in wheat plants. J. sci. of Food and Agric 323(1), 959-962.

Sitohy, M. and Sharaf, A. (1986). Effect of kinetin application on the yield of local and Foreign varieties of safflower plant and chemical composition. J. Agric. Sci. Mansoura Univ., Egypt 11(22): 474-484. 
Ziaein, A. M. and Malkout. (2002). Effect of $\mathrm{Fe}, \mathrm{Mn}, \mathrm{Zn}$ and $\mathrm{Cu}$ fertilization on the yield and grain quality of wheat. Plant Nutrition, 22: $978-20021$.

\section{دراسات كيميائيه حيوية علي تاثير كلا من الزنك والنحاس علي بعض فئ

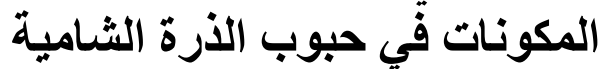

عبد العزيز لطفى شرف ـ رفعت صابر قسم الار اضى والمياه ـ كلية التكنولوجيا و التنميةــ جامعة الزقازيقـ الزقازيق-

اقيمت تجربة حقلية في مزر عة غز الة التابعة لمركز الزقازيق شرقية لدر اسة تاثيركلا

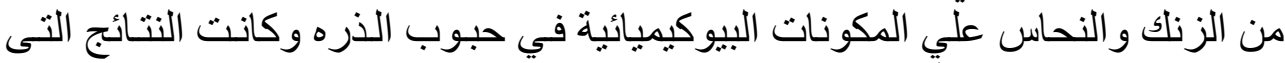
سجلت من هذه الاراسة كالتالي:

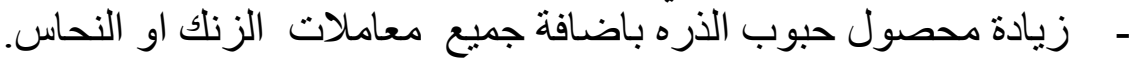

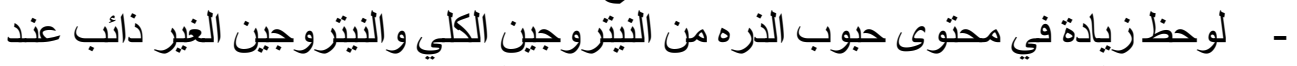

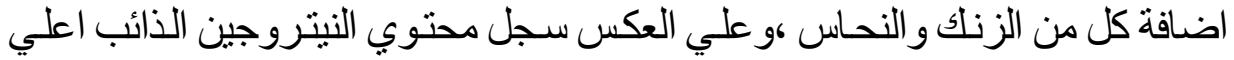

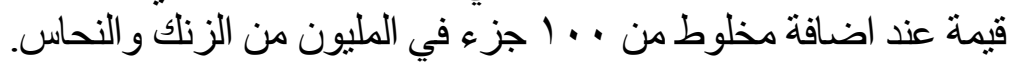

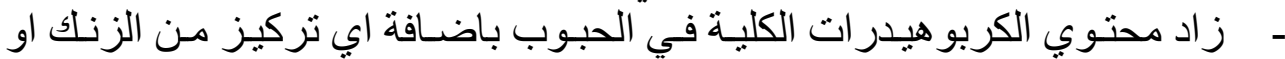

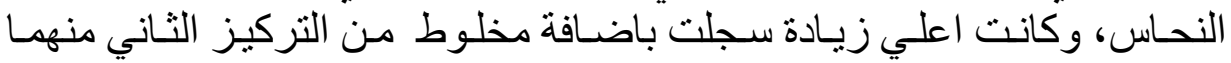

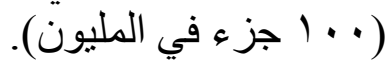

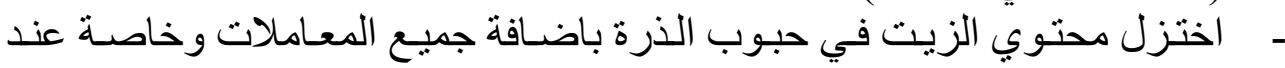

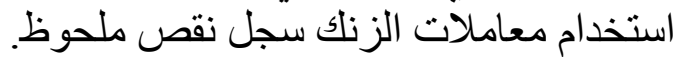

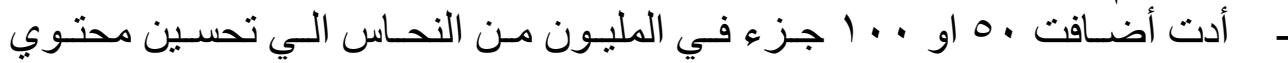

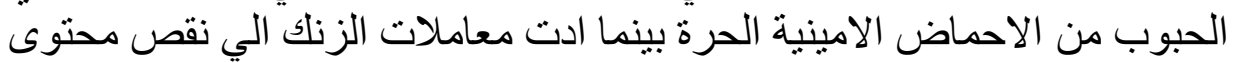
الحبوب من الاحماض الإمياض الإنية. - أدت إضافة معاملات الزناضك الي زيادة في محتوي كلا من الفوسفور و البوتاسيوم بينما ادت اضافة النحاس الي نقص في محتوب الزيان في الفوسفور. 